\title{
DEVELOPING CURRICULUM OF BACHELOR IN ELT PROGRAM BASED ON THE INDONESIAN NATIONAL QUALIFICATION FRAMEWORK (KKNI)
}

\author{
Amirudin Latif \\ Muhammadiyah University of Metro \\ amirpubian@gmail.com
}

\begin{abstract}
The study is intended to develop curriculum of bachelor in ELT Program based on the Indonesian National Qualification Framework (KKNI). The procedure of the curriculum development is adapted from a guidance book of the curriculum development for higher education published by RISTEKDIKTI. The subjects of the study are the lecturers and students of English Department Muhammadiyah University of Metro, English teachers, headmaster, English course owners, heads of private and state institution, and heads of regency and city education office. The result of the study is the curriculum documents such as graduate profiles, learning outcomes, study materials, the structure of curriculum, the semesterly course distribution, course description, syllabus, and lesson plan. The curriculum has been being implemented for two semesters. The students give positive response on the implementation of the curriculum.
\end{abstract}

Keywords: curriculum, ELT, KKNI

\section{INTRODUCTION}

Developing the curriculum of higher education referring to the Indonesian National Qualification Framework (KKNI) is now becoming special attention for every university. There are some universities which have implemented the KKNI based curriculum in their course learning, but more universities which have been struggling to develop the curriculum. Among those which have been designing the curriculum get grant from Dikti to push the completion of the curriculum development.

The KKNI based curriculum is developed based on (Perpres No. 8 2012) about KKNI. KKNI requires universities to produce the alumnus who have a major competency, supporting competency, and an additional competency as well as an acceptable qualification relevant to the job skill which is accepted in the job market. KKNI must be implemented in developing the curriculum of higher education based on (Permendikbud No. 73 2013) about the implementation of KKNI. 
According to (Perpres No. 8 2012), there are nine levels of qualification in KKNI namely level 1 for elementary education, level 2 for secondary school, level 3 for diploma I, level 4 for diploma II, level 5 for diploma III, level 6 for diploma IV and S1, level 7 for professional education, level 8 for magister, and level 9 for Doctor.

Bachelor belongs to the sixth level of qualification. The level 6 of KKNI as stated in appendix of (Perpres No. 8 2012) must have the following competencies namely. 1) The S1 graduates must be able to apply their expertise, use knowledge, technology, and art to solve the problem, and adapt in the situation encountered. 2) The S1 graduates must be able to master the theoretical concept of the certain knowledge generally and one of the specific knowledge deeply as well as to formulate the solution of the procedural problem. 3) The S1 graduate must be able to make an accurate decision based on the information and data analysis as well as to give guidance in selecting the alternative solution both individually and in group. 4) The S1 graduates are responsible for their own work as well as the result of the organization's work.

Developing the curriculum for bachelor must be suited with the level 6 in KKNI. It is in line with (Permendikbud No. 492014 Article 9 paragraph 2), which indicates there is a continuity of knowledge from level one to another level. Unless the curriculum is matched with the level 6 in KKNI, it will break the continuity of knowledge from the previous level or overlap to the next level.

Developing the KKNI based curriculum needs to review and evaluate the current curriculum to see the strength and weakness of the curriculum before having a new one (Solikhah, 2016). The S1 of ELT program of English Department of Teacher Training and Education Faculty Muhammadiyah University of Metro has been implementing the competency based curriculum since 2006. The curriculum was reviewed once in 2010. The curriculum weighs 160 credits which consist of MKPK course 10 credits, AIK course 12 credits, MKPB course 10 credits, MKKB course 9 credits, MBB course 10 credits, and MMK course 109 credits. There are some serial subjects whose contents overlap each other because there is no clear limitation on each subject. The distribution of the subjects in each semester is not good because there are some subjects which are placed in wrong semester. Second Language Acquisition, for example, is placed in the first semester while Action Research is in the seventh semester. In short, aside from the structure of the curriculum as well as the distribution of the 
subjects in each semester, the 160 - credit curriculum is so burdening for the students that some of them do not punctually finish the program.

Meanwhile, the quality assurance of the curriculum implementation is done every semester through evaluation on teaching in the semester. In the end of the semester, the students are assigned to score the teaching and learning activities done by a lecturer using the scoring instrument. Besides that, the other lecturers are also given chance to score their colleague from planning, implementing, and evaluating the course. The scoring results are submitted to the director of the quality assurance of Muhammadiyah University of Metro. The results are announced before starting a new semester.

Furthermore, measuring the quality of alumni produced from the curriculum implementation is also done by tracer study. The tracer study is done in 20 schools or other institutions which use the alumni of S1 ELT program of English Department of Muhammadiyah University of Metro. The alumni users are given the questionnaire of trace study to get the data of the quality of the alumnus who work in their institution. The questionnaire contains the items of the integrity (ethics and morality), skill and professionalism, English proficiency, information and technology mastery, communication ability, teamwork, and self development. The result of the tracer study shows that 1) the integrity of the alumnus achieves very good $50 \%$ and good $50 \%, 2)$ the skill and professionalism achieve very good $28 \%$ and good $72 \%$, 3) English proficiency achieves very good 40\%, good 56\%, and fair 4\%, 4) information and technology mastery achieves very good $18 \%$, good $66 \%$, and fair $16 \%, 5)$ communication ability achieves very good $37 \%$, good $56 \%$, and fair $7 \%, 6$ ) teamwork achieves very good $71 \%$, good $21 \%$, and fair $8 \%, 7$ ) self-development achieves very good $31 \%$, good $65 \%$, and fair $4 \%$.

However, the good implementation of the curriculum does not increase the interest of the alumni of Senior High School to join S1 of ELT program of English Department of Teacher Training and Education Faculty Muhammadiyah University of Metro. The program which has been operating since 2006 used to have a lot of students, but in the last 3 years it tends to have few students. The data of active students can be seen from the first year of the program namely 176 in 2006, 352 in 2007, 559 in 2008, 773 in 2009, 883 in 2010, 706 in 2011, 590 in 2012, 423 in 2013, 265 in 2014, 185 in 2015, and 175 in 2016. The S1 ELT program has undertaken accreditation twice 2010 with C score and 2014 with B score. Unluckily, the increase of accreditation score does not attract more entry students in the program. 
Considering the decrease of the students' interest in joining English Department of Muhammadiyah of Metro, developing KKNI based curriculum becomes the solution of the problem. Implementing KKNI based curriculum is supposed to increase the interest of the alumni of senior high school in joining ELT program at English Department of Muhammadiyah University of Metro. Hence, this study is intended to develop the curriculum of S1 ELT program based on the Indonesian national qualification framework (KKNI).

\section{METHOD}

This study uses research and development design which tries to develop the curriculum of S1 ELT program based on the Indonesian national qualification framework. The procedure of the curriculum development follows and adapts the steps proposed by Tomlinson and Masuhara (2004)given by the directorate general of learning and student affairs in a guidance book of the curriculum development for higher education (2016) such as conducting need assessment, doing comparative study, formulating graduate profiles, formulating learning outcomes, selecting study materials, designing the structure of curriculum, designing courses in every semester, developing course description, designing lesson plan, inviting experts, revising the curriculum, examining the curriculum, and legalizing the curriculum.

Need assessment involves stakeholders who probably use alumnus of S1 English Department of Teacher Training and Education Faculty of Muhammadiyah University of Metro such as teachers, headmaster, English course owners, heads of private and state institution, and heads of regency and city education office. Need assessment is intended to get input on the ideal graduate profiles of PBI UM Metro. Focus group discussion is done involving the stakeholders to give input and suggestion on formulation of the most preferable graduate profile.

Comparative study visit is preliminary activity done before developing curriculum. Four universities which have implemented KKNI based curriculum namely University of Ahmad Dahlan, State University of Yogyakarta, State University of Malang, and Muhammadiyah University of Malang are the target of the visit. The visit is intended to grasp a new insight on KNNI based curriculum and its implementation.

Formulating graduate profiles is done curriculum teamwork of PBI UM Metro using the data from need assessment and comparative study visit. Graduate profile is formulated by 
peeping the potential job vacancy which alumnus of PBI UM Metro probably obtains after graduation. Graduate profile must be supported learning outcome involving particular knowledge, skill, and attitude given by all of the courses in the curriculum.

Formulating learning outcome is done to portray the expected learning results which must be possessed the students and alumnus of PBI UM Metro after learning some courses or completion from their study. The learning outcome consists of knowledge, skill, and attitude. The learning outcome is formulated by curriculum task force involving association of study program under Muhammadiyah Universities.

Selecting study materials is done to support the learning outcomes which finally produce the potential graduate profiles. The study materials comprise of the learning courses in the structure of curriculum. The study materials which do not sustain the learning outcomes and graduate profiles must be dropped and changed with those covering the learning outcomes and graduate profiles. The study materials are selected under the charge of the curriculum task force team of PBI UM Metro involving association of English study program under Muhammadiyah Universities.

Designing the structure of curriculum is done to portray the compilation of the courses including the credit hours. The courses are born from the study materials. In the structure of curriculum, one study material may cover several courses. Meanwhile, the number of credit hour is determined by looking at the complexity of the course. The structure of curriculum is designed by curriculum task force team of PBI UM Metro.

Designing courses in every semester is done to describe the number of courses and credits which must be completed by the students in every semester. The course starts from basic continued to intermediate and advanced. The courses in every semester are also designed by curriculum task force team of PBI UM Metro.

Developing course description is in charge of the lecturer who handles the course. The course description explains the content of the course covering learning objectives, learning materials, learning activities and tasks, and evaluation. Course description is written in the form of paragraph.

Designing lesson plan is also in charge of the lecturer who handles the course. The lesson plan consists of learning outcome or competence standard, learning materials, learning activities, 
and evaluation. The lesson plans in this study contain student- centered learning activities. The lesson plan is developed as the guideline of course delivery.

Inviting the experts of curriculum is intended to give feedback on the curriculum with all of its inclusions. Head and secretary of association of English study program under Muhammadiyah universities are invited to give suggestion and critics on the curriculum which has been developed. The suggestion and critics from the experts are used for the curriculum revision.

After revision, the curriculum is tried out in the classroom learning course. Some lesson plans are implemented in the learning course. The students attending and joining the course are given questionnaires on the implementability of the lesson plan.

After the whole steps are well done, the curriculum is ready to legalize. As the rector signs the letter of decision on the curriculum implementation, the curriculum can be officially implemented.

\section{RESULTS AND DISCUSSION}

\section{Results}

The first activity in the curriculum development is conducting need assessment which involves the stakeholders such as teachers, headmasters, English course owners, heads of private and state institution, and heads of regency and city education office. The need assessment through focus group discussion results input data on the formulation of the graduate profiles of PBI UM Metro.

Having input data from focus group discussion, the graduate profiles are formulated. The graduate profiles describe the potential job vacancy which is probably possessed by alumnus of PBI UM Metro. The followings are the graduate profiles of PBI UM Metro.

1. A religious English teacher candidate.

2. An assisting researcher candidate in ELT, linguistics, and literature.

3. An developer for ELT program

4. A translator or interpreter

5. An entrepreneur 
A comparative study visit to the four universities which have implemented KKNI based kurikulum such as State University of Yogyakarta, University of Ahmad Dahlan, State University of Malang, and Muhammadiyah University of Malang gives the beneficial inputs on learning outcome formulation, study material selection, structure curriculum designing, semesterly course designing, course description development, syllabus development, and lesson plan development.

After conducting comparative study visit, some workshops on the curriculum development are done. First of all, workshop on formulating learning outcome is done. The head of PBI UM Metro assisted with the lecturers are discussing to formulate the learning outcome considering the graduate profiles which have been formulated.

The result of workshop on formulating learning outcome is presented in the following points.

\section{A. Attitudes}

1. Having fearness to God and showing the religious attitude.

2. Upholding the values of humanity in doing work based on religion dogma, morality, and ethics.

3. Internalizing the academic values, norms, and ethics.

4. Playing role as citizens who take pride and love of the homeland, have nationalism and sense of responsibility to the state and nation.

5. Giving appreciation on cultural diversity, views, religions, and beliefs, as well as the original findings of an opinion or any other person.

6. Giving contribution in improving the quality of life of the society, the nation, the country and the progress of civilization based on Pancasila.

7. Working together and having social sensitivity and concern for the community and the environment.

8. Obeying the law and discipline in the social and national life.

9. Showing a responsible attitude on the job in the field of expertise independently.

10. Internalizing the spirit of self-reliance, innovation, effort, and entrepreneurship. 
11. Having sincerity, commitment, strong willingness to develop the attitudes, values, and the ability of learners based on the values of local originality, the noble morality and motivation to act for the benefit of students and the public community.

12. Internalizing Al-Islam and Kemuhammadiyahan in all of both academic and nonacademic activities.

\section{B. General Skill}

1. Being able to apply logical, critical, systematic, and innovative thinking in the context of the development or implementation of science and technology that observe and apply the value of the humanities which are relevant to the expertise.

2. Having ability to examine the implications of the development or implementation of science, technology or art in accordance with the expertise based on rules, procedures and scientific ethics to produce solutions, ideas, designs, or art criticisms as well as to prepare scientific descriptions of the results of the study in the form of thesis or final report.

3. Having ability to make decisions appropriately in the context of problem solving in the area of the expertise, based on the result of the information and data analysis.

4. Having ability to manage learning independently.

5. Having ability to develop and maintain networks with counselors, colleagues both inside and outside the institution.

\section{Specific Skill}

1. Having proficiency both in spoken and written English in the daily or general, academic, and working context which is equivalent to the post-intermediate level.

2. Having proficiency both in spoken and written English on at least one English for specific purposes equivalent to intermediate level.

3. Having ability to adapt a positive target language user culture into the mother tongue culture. 
4. Having ability to plan, implement, manage, evaluate learning, and to improve the methods and processes of English as a foreign language according to the characteristics and needs of learners and stakeholders in accordance with process and quality standards.

5. Having ability to apply methods and learning process in English for specific purposes.

6. Having ability to plan and manage the resources in the organization of the class, school, and educational institutions which are under their responsibility and to evaluate the activities comprehensively.

7. Having ability to identify and analyze quality issues, relevance or access to English learning and present some alternative solutions as decision making materials.

8. Having ability to provide guidance to students in the scope of learning.

9. Having ability to use relevant information and communication technology for the development of education quality.

10. Having ability to apply language knowledge and English education to solve problems that arise in selected profession (English educator and education manager, researcher, translator, and educulture guide).

\section{Knowledge}

1. Mastering the theoretical concepts of language and techniques of oral and general English communications in the daily, public, academic, and equivalent to the postintermediate level of work.

2. Mastering the theoretical concepts of language and techniques of communicating oral and written English for specific purposes, in the daily or general, and academic context which are equivalent to the intermediate levels of work.

3. Mastering the theoretical concepts of literature, literacy, and Language learning.

4. Mastering the theoretical concepts of pedagogy.

5. Mastering the principles of developmental and educational psychology. 
6. Mastering the concepts and techniques of learning program development, presentation (methods and procedures), management, and evaluation of educating English learning programs.

7. Having knowledge of local originality and development.

8. Mastering the theoretical and practical concepts of research methods and data analysis in the field of ELT, linguistics, and literature.

9. Mastering Al-Islam and Kemuhammadiyahan.

After the learning outcomes are formulated, the workshop on selecting the study materials is done. The study materials are finally selected and divided into three categories namely core knowledge, supporting knowledge, and university courses. The core knowledge consists of English language skills, English language components, linguistics, literature, translation, English for Specific Purposes (ESP), English Language Teaching (ELT), and research. Next, the supporting knowledge consists of educational knowledge, internship, leadership, and entrepreneurship. The last, university course consists of general course, AIK, and AIK in English.

After being selected, each study material is broken down into some courses depending on its complexity. Thus, the curriculum consists of 78 courses with 148 credits. The 148 credit curriculum comprises of 136 credits for required courses and 12 credits for elective courses.

General course belonging to university course consist of Pancasila, Pendidikan Kewarganegaraan, Bahasa Indonesia, and Ilmu Alamiah Dasar. AIK also belonging to university course is broken down into AIK 1 to AIK 5. Educational course belonging to faculty course is divided into eight courses namely Pengantar Pendidikan, Kepramukaan, Belajar dan Pembelajaran, Perkembangan Peserta Didik, Magang Dasar, Magang Lanjut, Micro Teaching, and Magang Terapan. Meanwhile, the core courses of prodi are derived from seven study materials namely English skills and components, linguistics, English literature, ESP, ELT, research, and internship.

English skills and components consist of courses namely Intensive Course, Basic Listening, Intermediate Listening, Advanced Listening, Speaking for Everyday Communication, Speaking for Formal Interactions, Speaking for Academic Purposes, Public Speaking, Basic Reading, Intermediate Reading, Advanced Reading, Basic Writing, Paragraph Writing, Essay 
Writing, Academic Writing, Basic Vocabulary, Intermediate Vocabulary, Advanced Vocabulary, Basic Grammar, Intermediate Grammar, Advanced Grammar, English Debate, English Proficiency, Introduction to translation, Translation, Memorizing Quran I, Memorizing Qu'ran II, and Interpreting.

Linguistics is broken down into Introduction to Linguistics, Phonetics and Phonology, English Morphology, English Syntax, Semantics, Psycholinguistics, Second Language Acquisition, Cross Culture Understanding, Sociolinguistics, Discourse Analysis, and Pragmatics. Meanwhile, English literature consists of Introduction to English Literature, Poetry and drama, and Prose.

English Language Teaching (ELT) consists of Developing Language Teaching Media, Course Design (General English and ESP), Introduction to TEFL, Analysis of Eng. Curriculum \& Material Development, Language assessment, Developing Language Assessment, TEFL, Modern ELT models, Strategi Belajar Mengajar, ICT Assisted Learning. Meanwhile, English for Specific Purpose (ESP) consists of English for Young Learners, Entrepreneurship, English for Hotel and Tourism, and English for Business.

Research courses consist of Quantitative Research Methodology, Research Statistics, Qualitative Research Methodology, Seminar, and Undergraduate Thesis. Meanwhile, internship has two courses namely KKL and KKN.

After having the structure of curriculum, the workshop on designing semesterly courses is done. Semester 1 is dropped with 10 courses which consist of 6 credits belonging to university courses, 5 credits belonging to faculty courses, and 10 credits belonging to prodi courses. Thus, the twenty one credit semester consists of courses namely Pancasila, Pendidikan Kewarganegaraan, AIK I, Bahasa Indonesia, Pengantar Pendidikan, Kepramukaan, Intensive Course, Basic Vocabulary, Basic Grammar, and Memorizing Quran I.

Semester 2 is burdened with 11 courses with 22 credits. From 11 courses, 2 courses belongs to university courses, 2 courses belong to faculty courses, and 7 courses belong to prodi courses. Thus, the twenty two credit semester consists of courses namely AIK II, Ilmu Alamiah Dasar, Belajar dan Pembelajaran, Perkembangan Peserta Didik, Introduction to Linguistics, Basic Listening, Basic Reading, Speaking for Everyday Communication, Basic Writing, Developing Language Teaching Media, and Cross Culture Understanding. 
Semester 3 is supplied with 12 courses with 23 credits. One belongs to university course, two courses belong to faculty courses, and nine belong to prodi courses. Thus, the twenty three credit semester consists of AIK III, Magang dasar, Strategi Belajar Mengajar, Intermediate Listening, Intermediate Reading, Speaking for Formal Interactions, Paragraph Writing, Intermediate Grammar, Intermediate Vocabulary, Phonetics and Phonology, English Morphology, and Course Design (General English and ESP).

Semester 4 is burdened with 13 courses with 23 credits. One belongs to university course and twelve belong to prodi courses. Thus, the twenty thee credit semester consist of AIK IV, Introduction to TEFL, Analysis of English Curriculum and Material Development, Language assessment, Quantitative Research Methodology, Research Statistics, Advanced Listening, Advanced Reading, Speaking for Academic Purposes, Essay Writing, English Debate, English for Young Learners, and KKL. English Debate and English for Young Learners belong to elective courses; the rests belong to required courses.

Semester 5 consists of 11 courses; one university course, one faculty course, and nine prodi courses. The eleven courses are AIK V, Magang Lanjut, Developing Language Assessment, TEFL, Advanced Vocabulary, Advanced Grammar, Introduction to translation, Qualitative Research Methodology, Academic Writing, Introduction to English Literature, and Entrepreneurship.

Semester 6 consists of 11 courses; one faculty course and ten prodi courses. The eleven courses are Micro Teaching, Seminar, English Syntax, Semantics, ICT Assisted Learning, Public Speaking, Psycholinguistics, Second Language Acquisition, Translation, Poetry and drama, Modern ELT models. Public Speaking, Psycholinguistics, Poetry and drama, and Modern ELT models are elective courses, while the others are required ones.

Semester 7 consists of 10 courses; one faculty course and nine courses. The ten courses are Magang Terapan, English Proficiency, Sociolinguistics, Discourse Analysis, English for Hotel and Tourism, English for Business, Pragmatics, Prose, Interpreting, and KKN. Meanwhile, Semester 8 only has one course namely undergraduate thesis.

After the semesterly courses are designed, other documents such as course description, syllabus, and lesson plan are developed by lecturers through PEKERTI programs hosted by Muhammadiyah University of Metro in cooperation with Kopertis 2 Palembang. 
Inviting the experts in curriculum is done to have the feedback on the documents of curriculum which have been developed. Mr. Raden Muhammad Ali, M.Pd says that courses which do not support the graduate profile must be dropped. Mrs. Mauly Halwat Hikmat, P.hD says that the name of each course must reflect and describe its content. Meanwhile, three assessors from BELMAWA suggest that elective courses must be added.

\section{Discussion}

English curriculum based on KKNI is different from the previous one in several aspects. The present curriculum has 148 credits which consist of 136 credits for required courses and 12 credits for elective courses. Meanwhile, the previous curriculum contains 160 credits which consist of 150 credits for required courses and 10 credits for elective courses.

Naming courses shows different way between the present curriculum and the previous one. In the present curriculum, the name of the course reflects the content of the course. Rarely does the curriculum use the serial name of the course. For example, speaking for daily communication, speaking for formal communication, speaking for academic purposes, and public speaking are preferred in the present curriculum. In contrast, the previous curriculum would rather use speaking 1 , speaking 2 , speaking 3 , and speaking 4 .

The presence and absence of the course in the curriculum is also highlighted. There are some courses of the previous curriculum are deleted in the present curriculum. In contrast, in the present curriculum there are some new courses which never appear in the previous curriculum. Introduction to history of English Language and criticism on English Literature are the example of the courses which are deleted in the present curriculum. Meanwhile, memorizing quran, English debate, ICT assisted learning, modern ELT models, course design, English for business, English for young learners, English for hotel tourism, and pragmatics are new courses which never appear in the previous curriculum.

The graduate profiles formulated in the present curriculum give more job vacancies than that in the previous one. The present curriculum has five graduate profiles formulated through focus group discussion activity involving the stakeholders. The graduate profiles in the curriculum are becoming the candidate of a religious English teacher, an assistant of researcher, a developer of ELT program, a translator or interpreter, and entrepreneur. 
The first graduate profile, the candidate of a religious English teacher, is supported by courses namely Intensive course, Basic Listening, Intermediate Listening, Advanced Listening, Speaking for everyday communication, Speaking for formal Interaction, Speaking for academic purposes, Basic reading, Intermediate reading, Advanced reading, Basic writing, Paragraph writing, Essay writing, Academic writing, English debate, English proficiency, Basic vocabulary, Intermediate vocabulary, Advance vocabulary, Basic grammar, Intermediate grammar, Advanced grammar, Introduction to Linguistics, Phonetics and phonology, English morphology, English syntax, Semantics, Sociolinguistics, Psycholinguistics, Pragmatics, Discourse Analysis, Cross culture understanding, Second Language Acquisition, Introduction to English Literature, Poetry and drama, Prose, Analysis of English curriculum, Developing ELT media, ICT assisted learning, Learning material development, Course design, Introduction to TEFL, TEFL, Language Assessment, Developing Language Assessment, Modern ELT models, Quantitative research, Research statistics, Qualitative research, Seminar, Undergraduate thesis, Landasan Pendidikan, Belajar dan pembelajaran, Perkembangan peserta didik, Magang dasar, Magang lanjut, Micro teaching, Magang terapan, Pancasila, Pendidikan kewarganegaraan, Bahasa Indonesia, Ilmu Alamiah Dasar, Kepramukaan, AIK, Memorizing Quran I, Memorizing Quran II, and Kepramukaan.

The second graduate profile, the candidate of assisting researcher, is supported by courses Quantitative research, Research statistics, Qualitative research, Seminar, Undergraduate thesis, Analysis of English curriculum and material development, Developing ELT media, ICT assisted learning, Course design, Introduction to TEFL, TEFL, Language Assessment, Developing Language Assessment, Modern ELT models, Introduction to Linguistics, Phonetics and phonology, English morphology, English syntax, Semantics, Sociolinguistics, Psycholinguistics, Pragmatics, Discourse Analysis, Cross culture understanding, Second Language Acquisition, Introduction to English Literature, Poetry and drama, and Prose.

The third graduate profile, a developer of ELT program, is supported by courses namely Intensive course, Basic Listening, Intermediate Listening, Advanced Listening, Speaking for everyday, Speaking for formal interaction, Speaking for academic purposes, Basic reading, Intermediate reading, Advanced reading, Basic writing, Paragraph writing, Essay writing, Academic writing, English debate, English proficiency, Basic vocabulary, Intermediate vocabulary, Advanced vocabulary, Basic grammar, Intermediate grammar, Advanced grammar, 
Analysis of English curriculum and material development, Developing ELT media, ICT assisted learning, Course design, Introduction to TEFL, TEFL, Language Assessment, Modern ELT models, English for young learners, English for hotel and tourism, English for business, and Kepramukaan.

The fourth graduate profile, a translator or interpreter, is supported by courses namely Introduction to Linguistics, Phonetics and phonology, English morphology, English syntax, Semantics, Sociolinguistics, Psycholinguistics, Pragmatics, Discourse Analysis, Cross culture understanding, Second Language Acquisition, Introduction to English Literature, Poetry and drama, Prose, Basic vocabulary, Intermediate vocabulary, Advance vocabulary, Basic grammar, Intermediate grammar, Advance grammar, Introduction to Translation, Translation, and Interpreting.

The last graduate profile, an entrepreneur, is supported by courses namely English for young learners, English for hotel and tourism, English for business, Kepramukaan, Entrepreneurship, KKL, and KKN.

Meanwhile, the previous curriculum limits the graduate profile on becoming an English teacher. Thus, the alumni resulted from the previous curriculum only have an opportunity to be English teacher.

\section{CONCLUSION AND SUGGESTION}

\section{Conclusion}

The present curriculum of bachelor in ELT program is developed based on the national qualification framework (KKNI). The development of the curriculum goes through several steps namely need assessment, comparative study visit, formulating graduate profiles and learning outcomes, selecting the study materials, designing the structure of curriculum including credit hours, designing semesterly course, developing course description, developing syllabus and lesson plan, inviting experts, and try out.

The whole steps are done, and the study has produced the document of curriculum of bachelor in ELT program completely. The curriculum has 148 credits which consist of 136 credits for required courses and 12 credits for elective courses. The alumni produced by the 
curriculum are supposed to be a candidate of religious English teacher, an assisting researcher, a developer of ELT program, a translator or interpreter, and entrepreneur. The curriculum has been being implemented for two semesters. The students give positive response on the implementation of the curriculum.

\section{Suggestion}

The KKNI based curriculum needs to be implemented in order to have alumni who fulfill the demand of job market. The revision on the curriculum must be routinely done in five years by considering the need of the stakeholders. University courses and faculty courses which do not support the graduate profiles and the learning outcome of prodi must be removed from the curriculum. The discussion with the leaders of university and faculty on deleting the courses must be wisely done in order to have no internal conflict.

\section{BIOPROFILE}

Amirudin Latif is a certified English lecturer at Muhammadiyah University of Metro. He earned his Bachelor's degree in ELT from Open University, Indonesia in 2007 and Master's degree in ELT from State University of Malang, Indonesia in 2011. His interest is curriculum and materials development. His corresponding email: amirpubian@gmail.com 


\section{REFERENCES}

Belmawa. 2016. Panduan Penyusunan Kurikulum Pendidikan Tinggi. Ristekdikti

Peraturan Presiden Repbublik Indonesia No. 8 Tahun 2012 tentang Kerangka Kualifikasi Nasional Indonesia.

Permendikbud No. 49 tahun 2014 tentang Satandar Nasional Pendidikan Tinggi.

Permendikbud No. 73 tahun 2013 tentang Penerapan Kerangka Kualifikasi Nasional Indonesia Bidang Pendidikan Tinggi.

Solikhah, I. 2016. Pengembangan Model Kurikulum Pendidikan Bahasa Inggris Berbasis KKNI. Jurnal Konstrutivisme Vol. 8 No. 1 p-ISSN: 1979-9438 e-ISSN: 2445-2355. 